\title{
Humanitarian Politics and the Spectre of Illegitimacy
}

\author{
David Rieff \\ Writer and political analyst; author, most recently, of In Praise of Forgetting: Historical Memory and Its Ironies
}

\begin{abstract}
The political landscape in which the humanitarian movement took current form has changed radically. If humanitarian certainties have been upended, it is not in Sri Lanka, or even Syria or Afghanistan, but in the NGO response to the migration crisis in Greece and in the Mediterranean. However overstated, the claim of neutrality has always played an important role in establishing the legitimacy humanitarian action has enjoyed in Europe. But it is no longer possible, if it ever was, for relief workers to separate their ethical commitment to helping people in need from their political convictions, including about what the EU should stand for.
\end{abstract}

Keywords: global order, humanitarian politics, independence, legitimacy, migration crisis

Citing the celebrated opening sentence of the Communist Manifesto may seem an odd way to begin these modest reflections on the challenges the relief world is confronting, and the graver ones it is likely to confront over the course of the next decade. But just as the spectre of communism was haunting Europe in 1848, a spectre haunts the humanitarian international in 2018 - the spectre of illegitimacy.

A disclaimer is immediately necessary: if you believe that the importance of the changes that are taxing the established global order has been greatly exaggerated, then you will doubt that those changes are likely to pose any existential challenge to the humanitarian international, be it in terms of the efficacy of what relief groups do in the field or in terms of the political and moral legitimacy they can aspire to enjoy.

But if, on the contrary, you believe that we are living in the last days of a doomed system - established in the aftermath of World War II and dominated by the US then the humanitarian international is no more likely to survive (or to put the matter more starkly, be allowed to continue as currently constituted) than the other elements of that system. The reason for this should be self-evident: humanitarian action is an integral part of the system; indeed, it can be argued that for at least thirty years, the actions of relief agencies, above all the international private, voluntary ones, have served as the moral warrant for liberal globalisation. Only the human rights movement has been more central in this regard. ${ }^{1}$
To be sure, the perceived need for relief NGOs to play this role has diminished over the past decade, as they have been at least partially displaced by so-called socially responsible corporations and 'philanthrocapitalism' à la Bill and Melinda Gates, which increasingly are presented (and, of course, present themselves) as indispensable to any successful effort to combat poverty, hunger and disease in the poor world. ${ }^{2}$ Even so, the moral warrant that NGOs provide for the great Western powers is still viewed in Washington, Brussels and elsewhere as being of value. A US Secretary of State might not, today, go as far as Colin Powell when he told an assembly of relief NGOs that they were a 'tremendous force multiplier' for the US military, but even in the Donald Trump administration that sense of things is by no means wholly absent.

But if the view from Washington, Brussels, etc. may not have changed that much, the view of Washington, Brussels, etc., most certainly has.

For all its bad faith, its selective implementation and, in the battle spaces of the Long War, its instrumentalisation in the service of military strategy, development aid from the US, the EU and other Western donor governments has at least generally come with certain stipulations about human rights and relative autonomy for international relief NGOs in the field. The Chinese have no such agenda, and governments in the Global South have come to understand this perfectly. In short, there is no need to apply to Washington or Brussels when making the same application to Beijing comes at a 
considerably lower cost in terms of what has to be conceded vis-à-vis humanitarian access, let alone human rights guarantees.

The advent of a multipolar world poses an immediate challenge to the UN and Bretton Woods systems, as well as the Western hegemony they have sustained. And it should be obvious that this will have a profound effect on the relief world, if it hasn't already. Humanitarian independence has always been a relative concept at best. $^{3}$ For despite all their critical thinking about, and intermittently principled resistance to, the demands of major Western powers, relief agencies have operated to a very considerable degree under the direct aegis of these powers.

But humanitarian independence is not a complete fiction either. An accurate portrait is drawn in Humanitarian Negotiations Revealed, a book published by MSF-CRASH some years ago. Its authors argued that relief groups could be thought of as 'unreliable friends', constantly bargaining with donors (not to mention governments and insurgent groups in the countries in which they do their work). An important problem relief agencies face today, which is almost certain to grow worse in the coming decade, is that their success in negotiations can be in vain if donors don't have the power to make good on whatever has been agreed. And this is assuming major Western governments still believe it to be important to support relief agencies.

The political landscape in which the humanitarian movement took current form has changed radically. Even a 'centrist restoration' in the US and Europe might not be enough to prevent this movement's relative decline. In Giuseppe di Lampedusa's The Leopard, one of the principle characters says of the revolutionary era in which the novel is set: 'For things to remain the same, everything must change.' It seems to me that the relief world now faces a similar scenario. But it is hard to imagine what new terms of reference the humanitarian world can hope to establish with donors. After all, humanitarians are scarcely free agents here. Western donor governments and the UN system subservient to them may be witnessing their own eclipse, but it is not as if the relations of force between them and NGOs have changed as a result. And as the old saying goes, there's no tyrant like a petty tyrant.

If relief NGOs can weather the storm, there will be more areas in which they won't be able to operate, and more in which they will be able to operate but with less independence. The reality, though, is that things were headed in this direction anyway. The horrendous risk to humanitarian staff that now exists in war zones such as Syria has seen to that, as has an older phenomenon of strong regimes in the Global South unwilling to let NGOs operate without their nihil obstat. This dates back at least to the coming to power of Paul Kagame in Rwanda in 1994; and it was most flagrant in the curbs on the public declarations of NGOs imposed by the Sri Lankan government during and after its war against the Tamil Tigers.

Medical NGOs will almost certainly have an easier time than, say, groups focusing on community development or psycho-social care, but taken in aggregate the humanitarian world will be less transformed by a postNorth Atlantic world than the Northern human rights movement. ${ }^{4}$ Humanitarian action has never been a zerosum game, whereas that is precisely what human rights activism has to be to be morally coherent.

So far, Western relief organisations have experienced most challenges to their efficacy and political and moral legitimacy in the areas in which they have traditionally operated - that is to say, in the Global South. The staff of these organisations, including in leadership positions, now include many people from the South. But the concept of 'the mission', with its echoes of military campaigning and Jesuit proselytising, remains fundamentally the same. And it is an open question whether NGOs can sustain their legitimacy while they promote this concept.

How might NGOs respond? Will MSF leave the European cities in which its operational centres are based, and will the International Rescue Committee move from its New York headquarters to Dakar, Jakarta or Quito? At the moment, the answer of most major relief groups is implied by their stasis: no. But some measure of devolution appears necessary if they are to retain legitimacy.

The gravest political challenge NGOs face lies not in what is going on in the Global South but rather what is going on at home in the Global North, particularly in Europe. If humanitarian certainties have been upended, it is not in Sri Lanka, or even Syria or Afghanistan, but in the NGO response to the migration crisis in Greece and in the Mediterranean. For here, whether they like it or not, when they rescue people at sea who are trying to get to Europe, relief NGOs are involved not just in caritative work, whose deontology is relatively straightforward ethically; here, they are important actors in a profound political struggle, whose outcome, along with the response or non-response to climate change, is likely to define the next half century.

It is a commonplace to observe that the humanitarian world has never really known how to think about its own political role. The neutrality of the International Committee of the Red Cross, though not quite as complete as the organisation claims, is real enough in practice. But as the custodian of the Geneva Conventions, the ICRC has an international legal status that no other relief organisation can claim. Yes, major private voluntary relief groups have accepted various codes of conduct, but their adherence to these codes is ultimately voluntary. It 
remains the case that with sufficient funding any group of people could call itself a relief organisation. Such a group might not be allowed to participate in operations coordinated by the UN, but that is by no means all operations. The humanitarian field remains wide open to any and all who wish to engage in it.

In any case, the idea that humanitarian work can be apolitical is complete nonsense. While many, though not all, relief workers have come from and identified with the Left as citizens, relief organisations have claimed to be apolitical, hiding their ideology in the structures of the global system. But in making this claim, all they have really said is that their politics are those of liberal internationalism, whether in its American imperial form or its somewhat more egalitarian European iteration. And the great genius of liberalism is that it is the only political ideology in the history of the world that insists that it is not an ideology at all. But the politics of relief organisations has often been exposed, as in the 1980s when many effectively supported the Afghan mujahedeen in its fight against the Soviet army.

With the migration crisis, such contradictions are quite simply unsustainable. In the Global South, a European aid worker is just that: an aid worker, not a citizen. To be clear, this does not mean that a relief worker is unlikely to have strong political and moral views about what is going on in the country in which she or he is working; to the contrary, such a person will almost certainly have very passionate opinions and convictions. What she or he does not have is the moral obligation to take a political stance that citizenship imposes. ${ }^{5}$ No such 'opt out' is available with regard to the boat people at sea or the migrants in Calais and other French port cities, camped as they endeavour to find a way to get to Britain. The fact that where one stands with regard to the migrants has become the defining political and moral issue in the EU makes even a semblance of humanitarian 'neutrality' an impossibility. And rightly so.

At present, however, European relief NGOs seem to want to maintain the fiction that their response is purely a matter of ethics, not of ideology. Doing so has been a mistake. No one who spends time discussing the migration crisis with European aid workers could leave such an encounter in any doubt about where they stand on the EU: they accept more or less everyone who wants to come, though some do so arguing that there is no migration crisis but rather a xenophobia crisis. Since nobody can predict with any confidence what the numbers of migrants are likely to be, this seems like an argument that plays into the hands of the xenophobes, and as such strategically unwise. But the more important point is that it is no longer possible, if it ever was, to separate relief workers' political convictions about what the EU should stand for from their ethical commitment to helping people in need, rescuing people in danger of losing their lives and helping refugees once they have arrived.

The problem is that, however overstated, the claim of neutrality has always played an important role in establishing the legitimacy humanitarian action has enjoyed in Europe. In South Sudan in the 1990s, there were two kinds of relief group: those who professed neutrality and the very few who did not. The most prominent among the latter was Norwegian People's Aid, which used to run newspaper adverts stating that it wasn't neutral like MSF and others, but that it supported the rebels. It is understandable that mainline humanitarian groups working with migrants don't want to be so unequivocal. But sooner or later they will have to be, and not just on the personal blogs of individual aid workers.

Humanitarianism has weathered many crises, and perhaps it will weather this one as well. I certainly hope it will. But to do so, it will have to change radically, as radically as Matteo Salvini, Viktor Orbán and Alternative für Deutschland have transformed Europe's political, ethical and moral relations of force. And the only way to do this is to let go of humanitarian politics in favor of a politics of the pure and simple.

\section{Notes}

1 Obviously, despite the efforts of some relief groups to keep their distance from human rights NGOs, the consensus view is that both enterprises form part of the same larger global moral project.

2 Given the growing dependence of some of the most important international relief groups, as well as caritative arms of the UN system, on funding from the Gates Foundation and other new philanthropies created in its wake, the humanitarian world seems to have become increasingly resigned to this new dispensation; and realistically it is difficult to see how it could be otherwise.

3 Humanitarian NGOs have to a greater or lesser degree understood this. The real shock has been to the human rights movement, wedded for too long to a deterministic view that its triumph was inevitable. The panic, but more importantly the disorientation, one encounters these days in the publications of groups like Human Rights Watch and Amnesty International is an emblem of this.

4 This does not mean that coping with these changes will be easy or morally clear-cut for humanitarians. It is hardly surprising that when its medical facilities and hospitals in Syria were targeted and in many cases destroyed by Russian and Syrian government bombardment, MSF was at a loss as to how to respond, despite its brilliance in publicity.

5 An exception to this general rule about political engagement is Palestine, above all for Western European relief workers. But for so many young people in the EU, Palestine is the great international cause of their time, and as such, paradoxically, it also becomes a domestic issue for them. 